\title{
Effect of Potassium Levels on Growth and Productivity of Potato Varieties
}

\author{
Daniel Zeru Zelelew ${ }^{1}$, Sewa Lal ${ }^{1}$, Tesfai Tsegai Kidane², Biniam Mesfin Ghebreslassie ${ }^{1,3^{*}}$ \\ ${ }^{1}$ Department of Horticulture, Hamelmalo Agricultural College, Keren, Eritrea \\ ${ }^{2}$ Department of Agricultural Economics, Hamelmalo Agricultural College, Keren, Eritrea \\ ${ }^{3}$ Department of Horticulture, Jomo Kenyatta University of Agriculture and Technology, Juja, Kenya \\ Email: "bm95913@yahoo.com
}

Received 1 July 2016; accepted 20 August 2016; published 23 August 2016

Copyright (C) 2016 by authors and Scientific Research Publishing Inc.

This work is licensed under the Creative Commons Attribution International License (CC BY).

http://creativecommons.org/licenses/by/4.0/

(c) (i) Open Access

\section{Abstract}

Potato is one of the priority vegetable crops in the highlands of Eritrea growing as a key component in the livelihood systems of farmers. Potato requires a variety of balanced plant mineral nutrients for growth and development without which yield and qualities of tubers are reduced. Potato growers in Eritrea commonly use Di-ammonium Phosphate, Urea and Farmyard manure while potassium fertilizers are overlooked assuming that the soil is developed from $\mathrm{K}$ rich parent material and contains sufficient amount of $K$ to support crop growth. However this assumption is based on the result obtained forty-seven years ago. As a result the yield and quality of potato produced is very low as compared with international standards. Therefore the present experiment was conducted to assess the effect of potassium levels on growth and productivity of potato varieties at Hamelmalo Agricultural College, Eritrea. The experiment was conducted in factorial Randomized Complete Block Design with fifteen treatment combinations of three varieties (Ajiba, Zafira and Picasso) and five potassium levels $\left(0,75,150,225\right.$ and $300 \mathrm{~kg} \mathrm{~K}_{2} \mathrm{O} / \mathrm{ha}$ ) replicated thrice. The results of the study showed that both variety and potassium had significant effect on growth and yield parameters. Aerial stem number, leaf number per plant and plant height were increased with increasing $\mathrm{K}$ levels from 0 to $150 \mathrm{~kg}$ while number of days to maturity was increased in the range of $0-300 \mathrm{~kg} \mathrm{~K}_{2} \mathrm{O} / \mathrm{ha}$. The result also indicated that variety $A j i b a$ treated with $300 \mathrm{~kg} \mathrm{~K} / \mathrm{O} / \mathrm{ha}$ produced significantly highest tuber weight $(1.14 \mathrm{~kg})$ per plant and tuber yield of $49.38 \mathrm{t} / \mathrm{ha}$. The economic analysis result revealed that maximum gross margin 13,665.816 USD/ha was obtained from the application of $300 \mathrm{~kg} \mathrm{~K}_{2} \mathrm{O} / \mathrm{ha}$. On the whole, it gives an impression that using potassium fertilizer according to soil requirements will have good influence on growth and tuber yield.

${ }^{*}$ Corresponding author.

How to cite this paper: Zelelew, D.Z., Lal, S., Kidane, T.T. and Biniam, M.G. (2016) Effect of Potassium Levels on Growth and Productivity of Potato Varieties. American Journal of Plant Sciences, 7, 1629-1638. 


\section{Keywords}

\section{Eritrea, Potassium, Potato Varieties, Tuber Yield}

\section{Introduction}

Potato is one of the most important foods and cash crops cultivated worldwide under a wide range of climatic condition. At present it is the fourth most important food crop in terms of its production in the world, after wheat, rice and maize [1]. It is a source of both food and income in many of the densely populated highlands of SubSaharan Africa. Because of this double purpose, the potato crop plays an important role in the improvement of rural livelihood system of many countries [2]. According to [3] report, potato is considered among the highly recommended food security crop that can safeguard low-income countries from the risks posed by rising international food prices. In the recent years potato is becoming one of the key components in the livelihood systems of small-scale farmers in the highland and midland of Eritrea [4]. It is widely grown by small-scale farmers, contributing to food security as a direct food source and cash crop [5], with low input and low output practice [4]. Land holding and yield of potato in Eritrea vary among farmers and site with an estimated average of $11 \mathrm{t} / \mathrm{ha}$ [5]. But it was noted that production is higher (16 t/ha) during off-season (under irrigation) farming practices [4], although it is still low compared to the international standards.

Potato is a high yielding and exhaustive crop, thus requiring a variety of balanced plant nutrients for growth and development. Nitrogen (N), Phosphorus (P) and Potassium (K) are among the most important elements that are essential for potato productivity. In many potato producing areas, $\mathrm{N}$ and $\mathrm{P}$ fertilizers are widely used while $\mathrm{K}$ is usually ignored causing serious decrease of potassium level in the soils [6]. This is particularly true to Eritrean case due to the wrong assumption that the soil is developed from $\mathrm{K}$ rich parent material and contains sufficient amount of $\mathrm{K}$ to support crop growth [7]. However, many recent research findings proved that the fertility levels of East African soil, including Eritrea, are low because of continuous farming and degradation without replenishment [8]. Thus, low soil fertility is negatively affecting potato production in Eastern Africa, requiring accelerated agricultural intensification to optimize potato production (the authors added). Potato growers in Eritrea apply manures and fertilizers from limited resources only when they are available and affordable. However, the dose, time and methods of application are so different among the farmers and in different areas of production [4]. Potassium is an essential nutrient for the growth of crops, including potatoes [9]. It is absorbed by plants in larger quantity than any other nutrient after nitrogen [10]. Its role is well documented in photosynthesis, increasing enzyme activity; improving synthesis of protein, carbohydrates and fats, translocation of photosynthetate resulting higher productivity of potato tubers. $\mathrm{K}$ is an essential nutrient for all plants and has a major effect upon growth and yield of potatoes as well as the general health and vigor of the crop [11]. Moreover, it is particularly important in helping plants adapt to environmental stress such as drought, winter hardiness, tolerance to diseases, insect pests and frost damage [12]. It is also involved in activation of enzymes important to energy utilization, starch synthesis, $\mathrm{N}$ metabolism, and respiration. These enzymes are abundant in the meristematic tissue at the growing points (like sprouting tuber eyes) where cells are dividing and primary tissues are formed [10]. However, the most commonly used fertilizer types currently in Eritrea are Di-ammonium Phosphate (DAP), Urea and farmyard manure [4] with limited or no K application. Like farmers of other developing countries, Eritrean farmers have also shortage of available clean planting material leading to low yield; disease spread and low quality produce [13] and [14]. Reports of the Ministry of Agriculture, the State of Eritrea [15] also indicated that the high cost of inputs especially seeds; fungicides and fertilizers, and shortage of fertilizers both in quantity and type resulted in no application at all or were applied below the recommended rate. Many recent research activities on the application of $\mathrm{K}$ have been conducted in other potato producing neighbouring countries like Etiopia and promising results have been reported [16] and [17]. The current experiment was, therefore, designed to carry out a field trial on the effect of potassium levels on growth and productivity of potato varieties under Hamelmalo, Eritrea condition. The finding will undoubtedly contribute to enhancing potato productivity in the country and improving the livelihood of subsistent potato growers. 


\section{Materials and Methods}

\subsection{Site Characteristics, Soil Sampling and Analysis}

The study was conducted in the Research station, of Hamelmalo Agricultural College; Hamelmalo, Eritrea, located in ZobaAnseba $12 \mathrm{~km}$ North of Keren at 38 $27^{\prime} 42^{\prime \prime}$ East longitude, $15^{\circ} 52^{\prime 2} 21^{\prime \prime}$ North latitude and is situated at an altitude of 1285 meters above the sea level. Soil analysis on physico-chemical properties results $(0-30 \mathrm{~cm})$ showed that the soil texture was sandy loam with $0.03 \%$ nitrogen, $1.07 \mathrm{ppm}$ phosphorus, $0.09 \mathrm{meq} / 100 \mathrm{~g}$ of $\mathrm{K}^{+}$ and $0.11 \%$ organic matter.

\subsection{Experimental Set Up}

The experiment was conducted in plots (furrow) using factorial Randomized Complete Block Design with fifteen treatment combinations of three varieties (Ajiba, Zafira and Picasso) and five potassium levels (0, 75, 150, 225 and $300 \mathrm{~kg} \mathrm{~K} \mathrm{~K}_{2} \mathrm{O} / \mathrm{ha}$ ) replicated thrice. Full doses of potassium $\left(\mathrm{K}_{2} \mathrm{O}\right)$ were applied through band method at the time of planting as per the treatments to each experimental plot. Healthy pre-sprouted potato seed tubers were planted at a spacing of $75 \times 30 \mathrm{~cm}$. Irrigation was applied immediately after planting and subsequent irrigations were given as per the requirement of the crop. All other cultural practices, for all the treatments, were done uniformly.

\subsection{Data Collection and Analysis}

Observations of growth parameters like aerial stems per plant, plant height and number of leaves per plant were recorded when the crop exhibited maximum growth that is 60 days after emergence. Number of days to maturity for every treatment was determined when $50 \%$ of plants in every plot get mature. Data on number of tubers per plant, tuber diameter, tubers weight per plant and tuber yield per hectare were collected at the time of harvest. The data obtained were subjected to statistical analysis using the analysis of variance by GENSTAT software $\left(4^{\text {th }}\right.$ ed) and IBM SPSS statistical package version 20 at 5\% level of significance (95\% confidence limit) for the analysis of variance.

\subsection{Gross Margin Analysis}

Gross margin analysis was used to calculate the economic significance of potato tuber production as affected by potassium level application [18]. For this purpose, the mean marketable tuber yield data was adjusted down by ten percent to minimize plot management variation by farmers [16]. The average price of $1 \mathrm{q}$ of potato was taken as 36 USD. The price of potassium sulphate was estimated at $3 \mathrm{USD} / \mathrm{kg}$ based on the cost at the time of purchase. Therefore, to apply $100 \mathrm{~kg}$ of $\mathrm{K}_{2} \mathrm{O}$ you need to have $200 \mathrm{~kg}$ of sulphate of potash. Transportation cost of potato tuber yield at Hamelmalo area was $0.8 \mathrm{USD} / \mathrm{q}$. Gross revenue was calculated as average adjusted tuber yield $(\mathrm{q} / \mathrm{ha}) \times$ average price of one quintal of the crop. Total variable cost was calculated as the sum of all costs that are variable to specific treatment against the control. Gross margin was calculated by subtracting total variable cost from the gross revenue [18].

\section{Results and Discussions}

\subsection{Growth and Growth Components}

Potassium, varieties and their interactions had significant effects on all the growth parameters of potato varieties studied.

\subsubsection{Number of Aerial Stems per Plant}

The influence of $\mathrm{K}$ application on aerial stems per plant was found to be significant $(p<0.001)$. Number of aerial stems per plant had shown gradual increment with increasing potassium levels up to $150 \mathrm{~kg} \mathrm{~K} \mathrm{~K}_{2} \mathrm{O} / \mathrm{ha}$. Maximum number of stems per plant (4.17) was recorded from plots treated with $150 \mathrm{~kg} \mathrm{~K} / \mathrm{O} / \mathrm{ha}$ and minimum number of stems per plant (3.19) was obtained from control. In line with the current findings, [17] reported that stem number of the potato was influenced by the application of $\mathrm{K}$ fertilizer. This could be due to the vital role of $\mathrm{K}$ in enzymatic activities for energy utilization, starch synthesis, $\mathrm{N}$ metabolism, and respiration. These enzymes 
are abundant in the meristematic tissue at the growing points or sprouting tuber eyes where cells are dividing and primary tissues are formed [10]. Contradictory to the current findings [19] and [20] reported that potassium treatment was not found to have any significant effect on the number of aerial stems per plant.

Varietal effect on the number of aerial stems per plant was also highly significant $(p<0.001)$. The data presented in Table 1 revealed that the highest mean number of aerial stems per plant (6.23) was produced from the variety Ajiba. The differences in number of aerial stems produced by the crops could be influenced by genetic make-up of the plants [21]. Stem number per plant is affected by the number of eyes per seed tuber used [22] and in the current study the number of eyes of the seed tubers used was not uniform. Seed tubers of Ajiba were having slightly more number of eyes compared to the rest of the two varieties. As a result it had produced more number of aerial stems per plant than the other two. Based on interaction treatment of potassium and potato varieties, there were significant $(p<0.001)$ differential response of varieties to $\mathrm{K}$ in aerial stem production. Zafira and Picasso responded positively up to the application of $150 \mathrm{~kg} \mathrm{~K} \mathrm{~K}_{2} \mathrm{O} / \mathrm{ha}$. While Ajiba had showed sharp and positive response in stem number production with increasing potassium levels only up to $75 \mathrm{~kg} \mathrm{~K} / \mathrm{O} / \mathrm{ha}$. This could be due to variation in crop varieties in their physiology, morphology and growth habit and so do in their response to fertilizer application [16].

\subsubsection{Number of Leaves per Plant}

Potassium application had significant $(p<0.001)$ effect on number of leaves per plant produced. The data shown in Table 1 indicates that leaf number per plant had increased with increasing potassium levels from 0 - $150 \mathrm{~kg}$ $\mathrm{K}_{2} \mathrm{O} / \mathrm{ha}$. The highest leaf number (57.83) was obtained from application of $150 \mathrm{~kg} \mathrm{~K}_{2} \mathrm{O} / \mathrm{ha}$ while control gave the lowest (45.08) mean value. This is in close agreement with the findings of [20] and [6] who reported that highest leaves per plant were obtained from the application of $150 \mathrm{~kg} \mathrm{~K}_{2} \mathrm{O} / \mathrm{ha}$. The difference among the three varieties on number of leaves per plant was highly significant $(p<0.001)$. Ajiba had produced the highest leaf number per plant (78.13) followed by Zafira (48.83) and Picasso (35.48). Differences in growth characters of potatoes like leaf number are influenced by the genetic make-up of the varieties [23]. Varieties with more number of stems tend to have more vegetative growth leading to higher number of leaves [24]. In the current study, variety (Ajiba) which produced more number of stems also found to produce more number of leaves (Table 1). Regarding interaction effects; it is clearly indicated that the three varieties had responded to potassium levels in a different ways and showed significant $(p<0.001)$ effect on number of leaves per plant. Picasso had responded positively up to $150 \mathrm{~kg} \mathrm{~K} 2 \mathrm{O} / \mathrm{ha}$. While, leaf number produced from Ajiba and Zafira was increased up to $75 \mathrm{~kg}$ $\mathrm{K}_{2} \mathrm{O} /$ ha. The highest mean values (87 and 53.33 leaves per plant) for Ajiba and Zafira respectively were recorded when they were treated with $75 \mathrm{~kg}$ of $\mathrm{K}_{2} \mathrm{O} / \mathrm{ha}$. The minimum mean value of the three varieties was observed at $0 \mathrm{~kg}$ of $\mathrm{K}_{2} \mathrm{O}$ (control).

Table 1. Effects of K, potato varieties and their interaction on number of areal stems and leaves per plant.

\begin{tabular}{|c|c|c|c|c|c|c|c|c|c|c|}
\hline \multirow{3}{*}{$\mathrm{K}_{2} \mathrm{O}(\mathrm{kg})$} & \multicolumn{5}{|c|}{ Number of areal stem/plant } & \multicolumn{5}{|c|}{ Number of leaves per plant } \\
\hline & \multicolumn{5}{|c|}{ Variety } & \multicolumn{5}{|c|}{ Variety } \\
\hline & Ajiba & & Zafira & Picasso & Mean & Ajiba & & Zafira & Picasso & Mean \\
\hline 0 & 4.83 & & 2.68 & 2.05 & 3.19 & 64.83 & & 38.33 & 32.08 & 45.08 \\
\hline 75 & 7.33 & & 2.75 & 2.06 & 4.05 & 87.00 & & 53.33 & 33.00 & 57.78 \\
\hline 150 & 6.50 & & 3.67 & 2.33 & 4.17 & 82.33 & & 52.17 & 39.00 & 57.83 \\
\hline 225 & 6.33 & & 3.17 & 1.96 & 3.82 & 79.08 & & 50.33 & 37.00 & 55.47 \\
\hline 300 & 6.17 & & 2.50 & 1.83 & 3.50 & 77.42 & & 50.00 & 36.33 & 54.58 \\
\hline Mean & 6.23 & & 2.95 & 2.05 & & 78.13 & & 48.83 & 35.48 & \\
\hline \multirow{2}{*}{$\operatorname{LSD}(p=0.05)$} & & $\mathrm{K}_{2} \mathrm{O}$ & Variety & $\mathrm{K}_{2} \mathrm{O}^{*} \mathrm{Va}$ & & & $\mathrm{K}_{2} \mathrm{O}$ & Variety & $\mathrm{K}_{2} \mathrm{O} *$ Variety & \\
\hline & & 0.395 & 0.306 & 0.684 & & & 2.56 & 1.98 & 4.43 & \\
\hline CV \% & \multicolumn{5}{|c|}{10.9} & \multicolumn{5}{|c|}{4.9} \\
\hline
\end{tabular}




\subsubsection{Plant Height (cm)}

The effect of $\mathrm{K}$ treatments on plant height was statistically significant $(p<0.001)$.Plant height was increased as a result of $150 \mathrm{~kg} / \mathrm{ha} \mathrm{K}$ application $(40.36 \mathrm{~cm})$. Application of $300 \mathrm{~kg} \mathrm{~K} 2 \mathrm{O} /$ ha produced $(34.47 \mathrm{~cm})$ lower than control. [20] earlier observed that $\mathrm{K}_{2} \mathrm{O}$ enhanced uptake of $\mathrm{N}$ by plants when it is applied in the range 100-150 $\mathrm{kg} \mathrm{K}_{2} \mathrm{O} /$ ha resulting in maximum plant height. The author added that plant height became static and gradually decreased as $\mathrm{K}_{2} \mathrm{O}$ level increased beyond $150 \mathrm{~kg} / \mathrm{ha}$. In contradiction to the current findings [25] found that the vegetative growth parameters like plant height were gradually and significantly increased by increasing the level of potassium application from up to $285 \mathrm{~kg} \mathrm{~K} 2 \mathrm{O} / \mathrm{ha}$. Different potato varieties showed significant $(p<0.001)$ differences in their plant height responses. Ajiba was found to have highest plant height $(42.15 \mathrm{~cm})$ over the rest of the varieties studied and the lowest $(32.48 \mathrm{~cm})$ was obtained from Picasso. This could be attributed to the difference in their growth character which is being influenced by genetic make-up of the crop [26]. The interaction effect of $\mathrm{K}$ and varieties on plant height was significant. The three varieties had shown differential response to potassium application in which Zafira and Picasso gave their highest plant height of 43.33 and $34 \mathrm{~cm}$, respectively when they were treated with $150 \mathrm{~kg} \mathrm{~K} \mathrm{~K}_{2} \mathrm{O} / \mathrm{ha}$. Ajiba responded better at $75 \mathrm{~kg} \mathrm{~K}$. $/$ /ha and gave $45 \mathrm{~cm}$ (Table 2). Similarly, [27] who studied the effect of fertilizer and variety on the yield of sweet potato reported that interaction between variety and fertilizers had affected plant height significantly.

\subsubsection{Days to Maturity}

Based on $\mathrm{K}$ treatments days to maturity of potato crop were found to have significant $(p<0.001)$ differences. Table 2 indicates that increasing application of $\mathrm{K}$ was found to delay maturity and maximum (105.89 days) was recorded from plots treated with $300 \mathrm{~kg} \mathrm{~K} 2 \mathrm{O} / \mathrm{ha}$. Levels of certain nutrients like potassium affect not only yield, but also maturity and quality of the crop [28]. Potassium has significant role in building nutrient absorption capacity of crops especially, $\mathbf{N}$ [20]. The higher $\mathrm{N}$ status on the crop favors vegetative shoot growth, delays the initiation of the storage process and decreases growth rate and photosynthate accumulation in storage organ of potato [29]. However, [17] reported that application of potassium fertilization did not affect flowering and physiological maturity of potato. Number of days required for maturity were found to have significant $(p<0.001)$ variation among the varieties. Data depicted in Table 2 reveals that Zafira was found to be early and Picasso was late in their maturity with mean values of 92.07 and 117.33 days, respectively. This could be due to the fact that plant characteristics like maturity, number of main stem and tubers per plant, tuber size and shape of potato crop are influenced mainly by variety [23]. Based on the interaction treatments, days to maturity were found to have significant difference. All the varieties studied showed positive response to potassium application. Maturity of the varieties was gradually delayed with increasing potassium levels. Maximum days to maturity of the three varieties (122.33, 101.67 and 93.67 days) were recorded from Picasso, Ajiba and Zafira, respectively when they were treated with $300 \mathrm{~kg} \mathrm{~K} \mathrm{O} / \mathrm{ha}$. Similarly, three of them recorded their minimum mean values from control. This is ascribed to the cultivar or strains difference in their nutritional requirements as their mineral nutritional use efficiency is different and under genetic control [30].

Table 2. Effects of K, potato varieties and their interaction onplant height and number ofdays to maturity.

\begin{tabular}{|c|c|c|c|c|c|c|c|c|c|c|}
\hline \multirow{3}{*}{$\mathrm{K}_{2} \mathrm{O}(\mathrm{kg})$} & \multicolumn{5}{|c|}{ Plant height (cm) } & \multicolumn{5}{|c|}{ Number of days to maturity } \\
\hline & \multicolumn{5}{|c|}{ Variety } & \multicolumn{5}{|c|}{ Variety } \\
\hline & Ajiba & & Zafira & Picasso & Mean & Ajiba & \multicolumn{2}{|c|}{ Zafira } & Picasso & Mean \\
\hline 0 & 40.33 & & 35.08 & 29.42 & 34.94 & 93.67 & \multicolumn{2}{|c|}{90.67} & 114.33 & 99.56 \\
\hline 75 & 45.00 & & 36.33 & 33.33 & 38.22 & 93.67 & \multicolumn{2}{|c|}{92.00} & 115.00 & 100.22 \\
\hline 150 & 43.75 & & 43.33 & 34.00 & 40.36 & 94.33 & \multicolumn{2}{|c|}{92.00} & 116.00 & 100.78 \\
\hline 225 & 42.08 & & 33.67 & 33.00 & 36.25 & 95.33 & \multicolumn{2}{|c|}{92.00} & 119.00 & 102.11 \\
\hline 300 & 39.58 & & 31.17 & 32.67 & 34.47 & 101.67 & \multicolumn{2}{|c|}{93.67} & 122.33 & 105.89 \\
\hline Mean & 42.15 & & 35.92 & 32.48 & & 95.73 & \multicolumn{2}{|c|}{92.07} & 117.33 & \\
\hline \multirow{2}{*}{$\operatorname{LSD}(p=0.05)$} & & $\mathrm{K}_{2} \mathrm{O}$ & Variety & $\mathrm{K}_{2} \mathrm{O}^{*}$ Variety & & & $\mathrm{K}_{2} \mathrm{O}$ & Variety & $\mathrm{K}_{2} \mathrm{O} *$ Variety & \\
\hline & & 2.42 & 1.88 & 4.2 & & & 1.73 & 1.34 & 3.007 & \\
\hline CV \% & \multicolumn{5}{|c|}{6.8} & \multicolumn{5}{|c|}{1.8} \\
\hline
\end{tabular}




\subsection{Yield and Yield Components}

All yield and yield components studied in the present investigation were significantly influenced by the applied levels of potassium and varieties. However, only tuber number per plant was found to be significantly affected by the interaction treatments.

\subsubsection{Tuber Number per Plant}

Number of tubers per plant had shown gradual and significant $(p<0.001)$ increase with increasing potassium levels (Table 3). The highest tuber number per plant (9.08) was produced from the application of $300 \mathrm{~kg} \mathrm{~K} \mathrm{~K}_{2} \mathrm{O} / \mathrm{ha}$ while the lowest (6.92) was obtained from control. In a similar study [31] and [32] found that addition of $\mathrm{K}_{2} \mathrm{SO}_{4}$ fertilizer increased numbers of tubers produced. This could be due to the significant role of potassium on photosynthesis, favors high energy status which helps the crop for timely and appropriate nutrients translocation and water absorption by roots. This results in availability of more photosynthates to produce more number of tubers per plant [33]. There was also significant $(p<0.001)$ difference among potato varieties in their production of tubers per plant. The highest number of tubers per plant (11.11) was produced by Ajiba followed by Zafira (8.58). This is ascribed to the existence of differences among genotypes in their adaptability to the specific environment and nutrient use efficiency [16]. The interaction effect of potassium level and potato varieties on number of tubers per plant was statistically significant. Ajiba responded more to $\mathrm{K}$ up to $150 \mathrm{~kg} \mathrm{~K} \mathrm{~K}_{2} \mathrm{O} / \mathrm{ha}$, while Zafira showed slow increase in the range of 0 to $225 \mathrm{~kg} \mathrm{~K}$ O/ha but showed higher response as $\mathrm{K}$ level increased beyond $225 \mathrm{~kg} \mathrm{~K} \mathrm{~K}_{2} \mathrm{O} / \mathrm{ha}$. Picasso, on the other hand, showed steady response and number of tubers produced increased gradually with every increase of $\mathrm{K}$ levels (Table 3). Both Zafira and Picasso produced their higher number of tubers 10.57 and 5.61, respectively when they were treated with $300 \mathrm{~kg} \mathrm{~K} \mathrm{~K}_{2} \mathrm{O} / \mathrm{ha}$. All the varieties produced their minimum number of tubers per plant at zero application (control). The result revealsthat application of more than $150 \mathrm{~kg} \mathrm{~K}_{2} \mathrm{O} / \mathrm{ha}$ for Ajiba could be excessive dose that caused reduction in tuber production while it is too low for Zafira and Picasso, as potassium requirement of potato variety varies [34]. Similar results were reported by [27] for sweet potato variety.

\subsubsection{Tuber Diameter}

The results shown in Table 3 revealed that $\mathrm{K}$ level increased tuber diameter significantly $(p<0.001)$. The highest mean value $\left(5.34 \mathrm{~cm}\right.$ ) was obtained from application of $225 \mathrm{~kg} \mathrm{~K} \mathrm{~K}_{2} \mathrm{O} / \mathrm{ha}$ and the smallest tuber diameter (4.77 $\mathrm{cm}$ ) was recorded from control. Potassium requirement of potatoes increased with increasing tuber size as the functions of $\mathrm{K}$ is related with translocation of carbohydrates from leaves to tuber resulting in increased tuber size [31]. The fact that the experimental field was poor in K content, has led to better response of the crop to potassium treatment (Table 3). This is in accordance to the findings of [35]. The authors concluded that potassium application increases the size of tubers, especially, in low to medium soil types. [36] also noted that insufficient

Table 3. Effect of K, potato varieties and their interactionon tuber number per plant and tuber diameter.

\begin{tabular}{|c|c|c|c|c|c|c|c|c|c|c|}
\hline \multirow{3}{*}{$\mathrm{K}_{2} \mathrm{O}(\mathrm{kg})$} & \multicolumn{5}{|c|}{ Tuber No/plant } & \multicolumn{5}{|c|}{ Tuber Diameter (cm) } \\
\hline & \multicolumn{5}{|c|}{ Variety } & \multicolumn{5}{|c|}{ Variety } \\
\hline & Ajiba & \multicolumn{2}{|c|}{ Zafira } & Picasso & Mean & Ajiba & \multicolumn{2}{|c|}{ Zafira } & Picasso & Mean \\
\hline 0 & 9.22 & \multicolumn{2}{|r|}{7.76} & 3.78 & 6.92 & 4.54 & \multicolumn{2}{|c|}{4.89} & 4.87 & 4.77 \\
\hline 75 & 11.78 & \multicolumn{2}{|r|}{8.01} & 4.28 & 8.02 & 4.57 & \multicolumn{2}{|c|}{5.04} & 5.35 & 4.99 \\
\hline 150 & 12.14 & \multicolumn{2}{|r|}{8.13} & 4.83 & 8.37 & 4.85 & \multicolumn{2}{|c|}{5.07} & 5.36 & 5.09 \\
\hline 225 & 11.36 & \multicolumn{2}{|r|}{8.42} & 5.33 & 8.37 & 5.31 & \multicolumn{2}{|c|}{5.33} & 5.39 & 5.34 \\
\hline 300 & 11.06 & \multicolumn{2}{|r|}{10.57} & 5.61 & 9.08 & 4.97 & \multicolumn{2}{|c|}{4.93} & 5.59 & 5.16 \\
\hline Mean & 11.11 & \multicolumn{2}{|r|}{8.58} & 4.77 & & 4.848 & \multicolumn{2}{|c|}{5.052} & 5.312 & \\
\hline \multirow{2}{*}{$\operatorname{LSD}(p=0.05)$} & & $\mathrm{K}_{2} \mathrm{O}$ & Variety & $\mathrm{K}_{2} \mathrm{O} *$ Variety & & & $\mathrm{K}_{2} \mathrm{O}$ & Variety & $\mathrm{K}_{2} \mathrm{O} *$ Variety & \\
\hline & & 0.876 & 0.678 & 1.516 & & & 0.214 & 0.166 & NS & \\
\hline $\mathrm{CV} \%$ & \multicolumn{5}{|c|}{11.1} & \multicolumn{5}{|c|}{4.4} \\
\hline
\end{tabular}


$\mathrm{K}$ can result in reduced yields and produced smaller-sized tubers. The varieties had significant variations $(p<$ $0.001)$ with regard to their response. Picasso which produced larger sized tubers $(5.31 \mathrm{~cm})$ was found to be superior to the other varieties. Table 3 indicates that Ajiba which had highest tuber number produced smallest tuber size $(4.84 \mathrm{~cm})$. Similarly, [37] found that tuber diameter varied significantly among potato cultivars. This could be due to the peculiar genetic characteristics of the varieties: Ajiba, Zafira and Picasso produce large, large oval to long-oval, and very large to large with red eyes tubers, respectively [38]. However, the varieties did not show any significant difference in response to $\mathrm{K}$ on tuber diameter (Table 3).

\subsubsection{Tuber Weight (kg/plant)}

Increasing potassium application from 0 to $300 \mathrm{~kg} / \mathrm{ha}$ had increased tuber weight per plant significantly ( $p<$ 0.001). Maximum and minimum mean values of 0.91 and $0.54 \mathrm{~kg}$ per plant were produced from the application of $300 \mathrm{~kg} \mathrm{~K}{ }_{2} \mathrm{O} / \mathrm{ha}$ and control, respectively. This is because, higher application of $\mathrm{K}$ facilitates the crop to have better nutrients and water absorption that improve growth and development of the crop and ultimately tuber weight [31] [33] found sharp response of potato to $\mathrm{K}_{2} \mathrm{O}$ application on tuber weight. Table 4 further illustrated that tuber weight per plant had significantly $(p<0.001)$ influenced by varietal treatment. Ajiba was superior of the three varieties evaluated followed by Zafira. In agreement with this finding, [24] reported that significant differences between varieties in their seasonal yield and tuber production per plant. Such variation is ascribed to the fact that nutrient usage of potato varies among cultivars and different environmental conditions [28]. Nevertheless, all the varieties exhibited steady increase in their tuber weight with the increase of $\mathrm{K}$ levels. Slight tuber weight decrease was noted at $150 \mathrm{~kg} \mathrm{~K}_{2} \mathrm{O} / \mathrm{ha}$ for Ajiba as a result of sudden site specific late blight occurrence few days before crop maturity.

\subsubsection{Total Yield ( $\mathrm{t} / \mathrm{ha})$}

Results in Table 4 revealed that potato tuber yield increased with increasing potassium levels and had significant $(p<0.001)$ differences to all varieties. Highest tuber yield $(40.25 \mathrm{t} / \mathrm{ha})$ which is $39.20 \%$ yield advantage over the control was obtained from the application of $300 \mathrm{~kg} \mathrm{~K} 2 \mathrm{O} / \mathrm{ha}$. Consistent to the current results, [11] reported that gradual and significant increase of total tuber yield as a result of increased $\mathrm{K}$ level. Highest yield was obtained from the application of $285 \mathrm{~kg} \mathrm{~K} \mathrm{~K}_{2} \mathrm{O} / \mathrm{ha}$, the authors added. This is attributed to the importance of $\mathrm{K}$ in carbohydrate formation and transformation [39]. Moreover, according to [16], appreciable increase in yield was noted in response to the application of $\mathrm{K}$ fertilizers, especially from soils with very low or below critical $\mathrm{K}$ level. The varieties investigated also showed significant $(p<0.001)$ differences (Table 4). Ajiba produced highest tuber yield of $8.67 \%$ and $52.09 \%$ yield advantage over Zafira and Picasso, respectively. Contradictory to the current finding [40] noted that the effect of cultivar on tuber yield per unit area was not significant. The interaction between potassium and variety was not found to have any significant influence on the total yield of potato, although there was a trend of increase among the treatments. Yet, [16] reported that potato varieties showed significant difference in response to $\mathrm{K}$ application.

Table 4. Effect of K, potato varieties and their interaction on tuber weight per plant and tuber yield.

\begin{tabular}{|c|c|c|c|c|c|c|c|c|c|c|}
\hline \multirow{3}{*}{$\mathrm{K}_{2} \mathrm{O}(\mathrm{kg})$} & \multicolumn{5}{|c|}{ Tuber weight/plant (kg) } & \multicolumn{5}{|c|}{ Yield (t/ha) } \\
\hline & \multicolumn{5}{|c|}{ Variety } & \multicolumn{5}{|c|}{ Variety } \\
\hline & Ajiba & & Zafira & Picasso & Mean & Ajiba & & afira & Picasso & Mean \\
\hline 0 & 0.70 & & 0.61 & 0.31 & 0.54 & 30.99 & & 8.59 & 13.82 & 24.47 \\
\hline 75 & 0.88 & & 0.65 & 0.32 & 0.62 & 39.21 & & 2.94 & 14.40 & 28.85 \\
\hline 150 & 0.85 & & 0.80 & 0.42 & 0.69 & 37.83 & & 4.09 & 18.75 & 30.22 \\
\hline 225 & 0.92 & & 0.92 & 0.50 & 0.78 & 41.53 & & 10.85 & 22.17 & 34.85 \\
\hline 300 & 1.14 & & 1.01 & 0.59 & 0.91 & 49.38 & & 55.20 & 26.17 & 40.25 \\
\hline Mean & 0.90 & & 0.80 & 0.43 & & 39.79 & & 6.33 & 19.06 & \\
\hline \multirow{2}{*}{$\operatorname{LSD}(p=0.05)$} & & $\mathrm{K}_{2} \mathrm{O}$ & Variety & $\mathrm{K}_{2} \mathrm{O} * \mathrm{Va}$ & & & $\mathrm{K}_{2} \mathrm{O}$ & Variety & $\mathrm{K}_{2} \mathrm{O} *$ Variety & \\
\hline & & 0.127 & 0.098 & NS & & & 3.463 & 2.683 & NS & \\
\hline $\mathrm{CV} \%$ & \multicolumn{5}{|c|}{18.6} & \multicolumn{5}{|c|}{ 11.3.7 } \\
\hline
\end{tabular}




\subsection{Correlation Matrix among Growth and Yield Parameters of Potato}

Correlation analysis showed that, aerial stem number per plant had positive and significant correlations with plant height $(r=0.803)$, leaf number per plant $(r=0.958)$, tuber number per plant $(r=0.817)$, tuber weight per plant $(r=0.620)$ and total tuber yield $(r=0.626)$. Similar positive and strong correlation of primary stem number with plant height and tubers number was reported by [41]. These positive correlations indicate that as stem number produced per plant increased, the plant will have early ground cover then the plant will grow taller as to get more sun light. Taller plants will also have higher production of leaves per plant that favours more production of photosynthates. More production of photosynthates also favours the plant to produce bigger tuber size (weight) per plant subsequently more total tuber yield. This association indicates that an increased photosynthates in leaves in response to potassium fertilization had substantially contributed to enhanced potato production and productivity that could be through the production of more assimilates. This is supported by the conclusions of [24]. Contradictory to the current finding [22] reported that higher number of stems per plant to bring about yield reduction, through increase in number of small sized tuber. Moreover, in the current study, tuber number per plant had positive and significant correlation with tuber weight per plant $(\mathrm{r}=0.801)$ and total tuber yield $(\mathrm{r}=0.855)$. This indicates that as number of tubers produced by a single plant increases, total tuber weight per plant and overall tuber yield can be increased. However, it showed negative correlations with tuber diameter $(r=-0.416)$. As the number of tubers per plant increased tend to become smaller in size. This is in line with the findings of [23] who stated that tuber size of the harvested product depends on the total tuber yield and the number of tubers per $\mathrm{m}^{2}$. Total tuber yield had positive and significant correlation (0.462) with $\mathrm{K}$ application. This is because of the importance of $\mathrm{K}$ in carbohydrate formation and transformation and movement of starch from potato leaves to tubers [39].

\subsection{Gross Margin Analysis (USD/ha)}

Costs of inputs, like fertilizers and transportation were calculated for all treatments to determine the total variable cost. Fixed costs are constant as they do not vary in all the treatments. For this reason only gross revenue was calculated as to determine the highest gross margin (income above variable cost). The result revealed that the gross margin obtained from the potato varieties had increased for every additional variable cost. It was noted the gross margin increased as a result of $\mathrm{K}$ application. Maximum gross margin (13,665.816 USD/ha) was obtained from Ajiba treated with $300 \mathrm{~kg} \mathrm{~K} \mathrm{~K}_{2} \mathrm{O} / \mathrm{ha}$. The increase in gross margin from the crops for every addition of potassium levels could be due to the positive yield responses of the varieties used as a result of low soil fertility of the experimental field.

\section{Conclusion}

It is concluded that application of potassium fertilizers has significant and positive effect on the growth and yield of potato. There were significant differences among potato varieties in their performance and it was found that variety ajiba is the best and high yielding variety in the study area. Interactions of potassium by variety were significant and the highest yield (49.38 t/ha) was found from ajiba treated with $300 \mathrm{~kg} \mathrm{~K}_{2} \mathrm{O} / \mathrm{ha}$. The cost benefit analysis indicated that, growers can get reasonable economic benefit by considering $\mathrm{K}$ application for potato production. It is, therefore, recommended that potassium fertilizers should be introduced and included in the fertilizer packages of the potato growers at Hamelmalo and other areas of the country with similar soil conditions.

\section{Acknowledgements}

The authors are grateful to the Eritrean National Commission for Higher Education in collaboration with Hamelmalo Agricultural College (HAC) for funding and facilitating the research project.

\section{References}

[1] FAO (2008) Production Year Book. Food and Agriculture Organization of the United Nations, Rome.

[2] Gildemacher, P.R. (2012) Innovation in Seed Potato Systems in Eastern Africa. PhD Thesis, Wageningen University, Wageningen, The Netherlands. 
[3] FAO (2009) Potato and Food Price Inflation. International Year of the Potato 2008. Food and Agriculture Organization of the United Nations, Rome.

[4] Biniam, M.G., Githiri, S.M., Tadesse, M. and Remmy, W.K. (2014) Diagnostic Survey on Potato Production Practices in Eritrea. ARPN Journal of Agricultural and Biological Science, 9, 444-453

[5] Ministry of Agriculture (2010) Vegetable Crops Research Program. Annual Report of National Agricultural Research Institute, Halhale, Eritrea.

[6] Pervez, M.A., Ayyub, C.M., Shabeen, M.R. and Noor, M.A. (2013) Determination of Physiomorphological Characteristics of Potato Crop Regulated by Potassium Management. Pakistan Journal of Agricultural Sciences, 50, 611-615.

[7] Murphy, H.F. (1968) A Report on the Fertility Status and Other Data on Some Soils of Ethiopia. Bulletin, College of Agriculture, Haile Sellasie I University, Experiment Station, Dire Dawa, Ethiopia, No 44.

[8] Muriithi, M.M. and Irungu, J.W. (2004) Effect of Integrated Use of Inorganic Fertilizer and Organic Manures on Bacterial Wilt Incidence (BWI) and Tuber Yield in Potato Production Systems on Hill Slopes of Central Kenya. Journal of Mountain Science, 1, 81-88. http://dx.doi.org/10.1007/BF02919363

[9] Dampney, P., Wale, S. and Sinclair, A. (2011) Review Potash Requirements of Potatoes. Report of Agriculture \& Horticulture Development Board 2011.

[10] Havlin, J.L., Beaton, J.D., Tisdale, S.L. and Nelson, W.L. (2005) Soil Fertility and Fertilizers: An Introduction to Nutrient Management. 7th Edition, Pearson Educational, Inc., Upper Saddle River, New Jersey.

[11] Abd El-Latif, K.M., Osman, E.A.M., Abdullah, R. and Abdel Kader, N. (2011) Response of Potato Plants to Potassium Fertilizer Rates and Soil Moisture Deficit. Advances in Applied Science Research, 2, 388-397.

[12] Brady, N.C. and Weil, R.R. (2002) The Nature and Properties of Soil. 13th Edition, Prentice Hall, Upper Saddle River, New Jersey.

[13] Tadesse, M. (2000) Manipulating the Physiological Quality of in Vitro Plantlets and Transplants of Potato. PhD Thesis, submitted to Wageningen University, The Netherlands.

[14] Biniam, M.G., Githiri, S.M., Tadesse, M. and Remmy, W.K. (2014b) Potato Seed Supply, Marketing and Production Constraints in Eritrea. American Journal of Plant Sciences, 5, 3684-3693. http://dx.doi.org/10.4236/ajps.2014.524384

[15] Ministry of Agriculture (2011) Annual Report. Horticulture Division Report, Asmara, Eritrea.

[16] Haile, W. (2009) On Farm Verification of Potassium Fertilize Effect on the Yield of Irish Potato Grown on Acidic Soils of Hagere Selam, Southern Ethiopia. Ethiopian Journal of Natural Resources, 11, 207-222.

[17] Abay, A. and Sheleme, B. (2011) The Influence of Potassium Fertilizer on the Production of Potato (Solanum tuberosum L.) at Kembata in Southern Ethiopia. Journal of Biology, Agriculture and Healthcare, 1, 1-12.

[18] Kay, R.D., Edwards, W.M. and Duffy, P.A. (2012) Farm Management. 7th Edition, McGraw-Hill Companies, Inc., New York.

[19] Al-Moshileh, A.M. and Errebi, M.A. (2004) Effect of Various Potassium Sulfate Rates on Growth, Yield and Quality of Potato Grown under Sandy Soil and Arid Conditions. IPI Regional Workshop on Potassium and Fertigation Development in West Asia and North Africa, Rabat, 24-28 November 2004.

[20] Noor, M.A. (2010) Physiomorphological Determination of Potato Crop Regulated by Potassium Management. Ph.D. Thesis, Institute of Horticultural Sciences University of Agriculture, Faislabad.

[21] Sajjan, A.S., Shekhargounda, M. and Badanur (2002) Influence of Data of Sowing, Spacing and Levels of Nitrogen on Yield Attributes and Seed Yield of Okra. Ikamataka. Journal of Agricultural Science, 15, 267-274.

[22] Iritani, W.M., Weller, L.D. and Knowles, N.R. (1983) Relationship between Stem Numbers, Tuber Set and Yields of Russet Burbank Potatoes. American Potato Journal, 60, 423-431. http://dx.doi.org/10.1007/BF02877248

[23] Van der Zaag, W.D.E. (1992) Potatoes and Their Production in the Netherlands. 3rd Edition, Netherlands Potato Consultative Institute, $\mathrm{CH}$ the Hague. www.potato.nl

[24] Abubaker, S., AbuRayyan, A., Amre, A., Alzu'bil, Y. and Hadidi, N. (2011) Impact of Cultivar and Growing Season on Potato under Center Pivot Irrigation System. World Journal of Agricultural Sciences, 7, 718-721.

[25] Asmaa, R.M. and Magda, M.H. (2010) Increasing Productivity of Potato Plants by Using Potassium Fertilizer and Humic Acid Application. International Journal of Academic Research, 2, 83-88.

[26] Enujeke, E.C. (2013) Effects of Variety and Spacing on Growth Characters of Hybrid Maize. Asian Journal of Agriculture and Rural Development, 3, 296-310.

[27] Ali, M.R., Costa, D.J., Abedin, M.J., Sayed, M.A. and Basak, N.C. (2009) Effect of Fertilizer and Variety on the Yield of Sweet Potato. Bangladesh Journal of Agricultural Research, 34, 473-480. http://dx.doi.org/10.3329/bjar.v34i3.3974

[28] Peirce, L.C. (1987) Vegetables: Characteristics, Production and Marketing. John Wiley and Sons, Inc., Hoboken.

[29] Gunasena, H.P.M. and Harris, P.M. (1971) The Effect of CCC, Nitrogen and Potassium on Growth and Yield on Two 
Varieties of Potato. The Journal of Agricultural Science, 76, 33-52. http://dx.doi.org/10.1017/S0021859600015604

[30] Marschner, H. (1995) Mineral Nutrition of Higher Plants. 2nd Edition, Academic Press Limited, San Diego.

[31] Adhikary, B.H. and Karki, K.B. (2006) Effect of Potassium on Potato Tuber Production in Acid Soils of Malepatan, Pokhara. Nepal Agriculture Research Journal, 7, 42-48.

[32] Wibowo, C., Wijaya, K., Sumartono, G.H. and Pawelzik, E. (2014) Effect of Potassium Level on Quality Traits of Indonesian Potato Tubers. Asia Pacific Journal of Sustainable Agriculture Food and Energy, 2, 11-16.

[33] Bergmann, W. (1992) Nutritional Disorders of Plants Development, Visual and Analytic Diagnosis. Gustav Fischer, Jena.

[34] Rana, M.K. (2008) Olericulture in India. Kalyani Publishers, Ludhiana.

[35] Bansal, S.K. and Trehan, S.P. (2011) Effect of Potassium on Yield and Processing Quality Attributes of Potato. Karnataka Journal of Agricultural Sciences, 24, 48-54.

[36] Tindall, T. and Westermann, D.T. (1994) Potassium Fertility Management of Potatoes. University of Idaho Potato School (Mimeo). Idaho State University, Pocatello.

[37] Abong, G.O., Okoth, M.W., Imungi, J.K. and Kabira, J.N. (2010) Evaluation of Selected Kenyan Potato Cultivars for Processing into Potato Crisps. Agriculture and Biology Journal of North America, 1, 886-893. http://dx.doi.org/10.5251/abjna.2010.1.5.886.893

[38] NIVAP (2011) Netherland Catalogue of Potato Variety. AC Den Haag, The Netherlands. www.nivap.nl

[39] Van der Zaag, P. (1981) Soil Fertility Requirements for Potato Production. Technical Information Bulletin 14, CIP, Lima.

[40] Vaezzadeh, M. and Naderidarbaghshahi, M. (2012) The Effect of Various Nitrogen Fertilizer Amounts on Yield and Nitrate Accumulation in Tubers of Two Potato Cultivars in Cold Regions of Isfahan (Iran). International Journal of Agriculture and Crop Sciences, 4, 1688-1691.

[41] Biniam, M.G., Githiri, S.M., Tadesse, M. and Remmy, W.K. (2016) Morphological Diversity of Farmers’ and Improved Potato (Solanum tuberosum) Cultivars Growing in Eritrea. Journal of Plant Studies, 5, 63-71. http://dx.doi.org/10.5539/jps.v5n2p63

\section{Submit or recommend next manuscript to SCIRP and we will provide best service for you:}

Accepting pre-submission inquiries through Email, Facebook, LinkedIn, Twitter, etc.

A wide selection of journals (inclusive of 9 subjects, more than 200 journals)

Providing 24-hour high-quality service

User-friendly online submission system

Fair and swift peer-review system

Efficient typesetting and proofreading procedure

Display of the result of downloads and visits, as well as the number of cited articles

Maximum dissemination of your research work

Submit your manuscript at: http://papersubmission.scirp.org/ 